\begin{tabular}{|c|c|c|}
\hline & Int.J.Curr.Microbiol.App.Sci (2021) 10(09): 38-53 & \\
\hline EXCEIIFNT & $\begin{array}{l}\text { International Journal of Current Microbiology and Applied Sciences } \\
\text { ISSN: 2319-7706 Volume } 10 \text { Number } 09 \text { (2021) } \\
\text { Journal homepage: http://www.ijcmas.com }\end{array}$ & 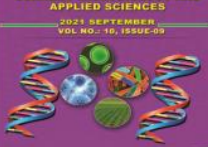 \\
\hline $\begin{array}{l}\text { EXCELLENT } \\
\text { PUBLISHERS }\end{array}$ & & \\
\hline
\end{tabular}

Original Research Article https://doi.org/10.20546/ijcmas.2021.1009.005

\title{
Extent of Adoption of Recommended Poultry Farming Practices by the Farmers
}

\author{
Hanuman Sahay Bunkar* and G. S. Bangarwa \\ Department of Extension Education, SKN College of Agriculture, Jobner, \\ Jaipur-303 329, India \\ *Corresponding author
}

Keywords

Extent of adoption, mean per cent score

Article Info

Accepted:

10 August 2021

Available Online:

10 September 2021

\section{A B S T R A C T}

The poultry production in our country has made a significant progress over the years due to research and development thrust of the government and organized private sector. Poultry farming is considered as an important tool for self-employment as it offers vast scope for generating income in socially and economically backward areas. No other livestock production programme in our country has made as much progress in a short period as the poultry sector has made. The revolutionary changes made in poultry industry in the last four decades is a matter of great pride. The poultry sector provides livelihood to nearly one lakh farmers and contributes to a great extent to the national income. In Rajasthan, poultry industry is a live segment and source of revenue to the government. In the last five decades, Jaipur region has made manifold progress in the development of the poultry sector. Jaipur district is one such districts which has made a great headway in the promotion of poultry sector. With more than 14889 organized poultry farms, it has engaged more than 45000 people directly or indirectly.

\section{Introduction}

In India, about 65 per cent of the population is engaged in agriculture and rearing of livestock, subsidiary to agriculture. There exists a symbiotic relationship in men-landlivestock ecosystem. Livestock comprising of mainly cattle, buffaloes and poultry have a complementary, supplementary and sustainable relationship with crop under mixed farming system prevalent in our country.
The origins of the poultry industry can be traced back to India. The modern crossbreed hen owes its ancestry to the Red Jungle fowl of India. However, poultry farming as a commercial enterprise is a recent phenomenon in our country. Poultry occupies a pivotal position among livestock based vocations to bring about rapid economic growth particularly benefiting the weaker sections of the farmers. Further, it needs low capital 
investment and yet assures quick returns, within weeks in case of broilers and months in case of layers.

\section{Materials and Methods}

To measure the adoption by respondents, a adoption index developed by Narender Paul (2003) was adopted with slight modification like inclusion of temperature and light regulation and also increasing the statements of sub practices based on expert opinions and converted the questions form after receiving the response from subject matter specialists of different poultry departments, Directorate of Extension Education R.A.U., Bikaner and MPUAT, Udaipur, poultry department in veterinary college, Bikaner, poultry training centre, Jaipur, Animal Husbandry department Jaipur, Agricultural University S.K. Nagar, Gujarat, NDRI Karnal, HAU Hissar, IARI New Delhi, poultry training centre, Ajmer, extensionists of department of extension education, S.K.N. College of Agriculture Jobner but basic theme of questions was kept the same. To measure the extent of adoption, an adoption index was specifically prepared containing 10 important major practices of poultry production. To convert responses of the respondents into numerical data, the adoption index so formulated was quantified. This quantification was done keeping in view the responses i.e., adopted and not adopted at all and; scores of 1 and 0 were assigned to these responses, respectively. The adoption index was calculated as:

$$
\begin{aligned}
& \text { Total adoption score obtained } \\
& \text { by the respondents }
\end{aligned}
$$

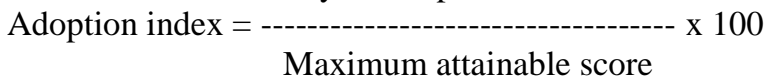

\section{Results and Discussion}

The findings of adoption of the recommended poultry farming practices by the poultry farmers have been presented in sub heads-
Adoption of the recommended poultry farming practices by the poultry farmers

Regarding the adoption of the recommended poultry farming practices by the poultry farmers have been presented in table 1. The data in table. 1 and also reveal that regarding adoption level of all the poultry farmers, 141 respondents (71.61 per cent) were having medium adoption whereas, 21 (9.21 per cent) and 38 (19.18 per cent) of respondents, were having high and low adoption respectively about recommended poultry farming practices.

Regarding the adoption of large poultry farmers, 52 respondents (61.90 per cent) were having medium adoption whereas, 16 (19.05 per cent) of equal respondents, were having high and low adoption respectively about recommended poultry farming practices. Regarding the adoption of medium poultry farmers, 53 respondents (77.94 per cent) were having medium adoption whereas, 3 (4.41 per cent) and 12 (17.65 per cent) of respondents, were having high and low adoption respectively about recommended poultry farming practices. Regarding the adoption of small poultry farmers, 36 respondents $(75.00$ per cent) were having medium adoption whereas, 2 (4.17 per cent) and 10 (20.83 per cent) of respondents were having high and low adoption respectively about recommended poultry farming practices.

Looking to the farmers category-wise analysis of the adoption level regarding recommended poultry farming practices, it was observed that majority of all the three categories viz., large, medium and small farmers had low to medium adoption of recommended poultry farming practices. The low to medium adoption level might be attributed to fear among the farmers about innovations, illiteracy, less exposure to information sources, non-availability of the literature about the recommended poultry farming practices. It means that literacy and 
participation in poultry training programmes by the respondents appeared to be responsible for their higher or lower adoption about recommended poultry farming practices. These findings are supported by findings of Podikunju (1999), Patel et al., (1999-2000) and Mundhawa and Patel (1999-2000) and Jat and Yadav (2009).

Category-wise comparison between different categories of poultry farmers in adoption of the recommended poultry farming practices

It is the general notion among the people that the adoption of recommended poultry farming practices varies in different categories of farmers. With this view in mind a comparison was made in the adoption of recommended poultry farming practices of different categories of farmers by applying ' $Z$ ' test. The statical data regarding this aspect have been presented in Table 2

The data in the table 2 show that the calculated value of ' $Z$ ' for large and medium farmers was 1.68 , which was statistically nonsignificant at one per cent level of probability. Thus, it may be concluded that there was a non-significant difference between the adoption of large and medium farmers about recommended poultry farming practices.

Hence, the null hypothesis $\mathrm{H}_{02.1}$ was accepted. Similarly a significant difference between large and small farmers has also been observed with regard to the adoption of about recommended poultry farming practices, as the calculated value of ' $Z$ ' was 2.76 , which was significant at one per cent level of probability. Hence the null hypothesis $\mathrm{H}_{02.2}$ was also rejected. The data in table 2 further elucidate that the calculated value of ' $Z$ ' for medium and small farmers regarding adoption of about recommended poultry farming practices was significant (4.31) at one per cent level of probability.

Hence the null hypothesis $\mathrm{H}_{02.3}$ was rejected. The ' $Z$ ' values indicate that there was a non significant difference between large and medium and significant difference between large and small farmers and medium and small farmers in adoption of the recommended poultry farming practices. This shows that large farmers might have more exposure, frequent contact with poultry training centres and more literacy were found in comparison to the medium and small poultry farmers. These findings are in agreement with the findings of Bhati et al., (1997-98) and Jagadeeshwara et al., (1997-98) and Jat and Yadav (2012).

\section{Practice-wise adoption of poultry farmers about the recommended poultry farming practices}

To explore the practice wise adoption of poultry farmers about the recommended poultry farming, ten practices namely chick procurement, brooding, litter management, temperature and light regulation, feeding, watering, equipment and spacing, disease management, sanitation and record keeping and marketing practices of poultry farming, scrutinized by experts were considered.

\section{Adoption of recommended chick procurement practices by the poultry farmers}

The adoption of recommended poultry farming practices by the poultry farmers were measured for all the eight important sub practices of chick procurement practice. The data in table 3 and indicate that out of eight practices of chick procurement, "Purchasing of chicks from reputed hatchery" adopted by poultry farmers was occupied the highest position (82.60 MPS), hence it was ranked first. The second, third, fourth and fifth ranks were awarded to the practices "Purchasing 
chicks of recommended breed" (80.95 MPS), "Checking wings, legs, eyes etc. of chicks while purchasing" (80.42 MPS), "Ensuring optimum weight of chicks during purchase" (80.34 MPS) and "Releasing chicks from the boxes at the earliest" (77.92 MPS), respectively.

The sixth and seventh ranks were assigned to "Counting chicks before keeping them in brooder" (77.51 MPS) and "Keeping a uniform lot of birds" (77.18 MPS), respectively. The last eighth rank was awarded to the least adopted practice "Purchasing chicks from a nearby hatchery” (76.36 MPS).

The data in table 3 further depict that among the poultry farmers, large farmers were found to have highest adoption (80.17 MPS) whereas, lowest adoption of recommended chick procurement practices was found among small farmers(79.31 MPS).

It might be concluded that the poultry farmers were found to have higher adoption of eight chick procurement practices.

It might be due to the fact that the poultry farmers might have benefited through poultry training programmes and they were well versed about the healthy chicks which should be purchased from well known and reliable source.

They were also well awared about norms and regulations on hatchery and farm management than poultry farmers.

These findings are supported with the findings of Goswami (2001).

\section{Adoption of recommended brooding practices by the poultry farmers}

The adoption of recommended poultry farming practices by the poultry farmers were measured for all the eleven important practices of brooding. The data in table 3 and indicate that out of eleven practices of brooding, "Dipping beaks of chicks after receiving from hatchery" adopted by poultry farmers was occupied the highest position (83.21 MPS), hence it was ranked first.

The second, third, fourth, fifth, sixth, seventh and eighth ranks were awarded to the practices "Providing proper feed and water in brooder house" (82.23 MPS), "Use of artificial brooding" (80.27 MPS), "Use of chick guard" (79.94 MPS), "Preparing brooder house before arrival of chicks" (79.03 MPS), "Use of thermometer for measuring temperature fluctuations" (76.77 MPS), "Providing feed to the day old chicks on old newspapers" (76.63 MPS) and "Spreading required thickness of bedding material on brooding floor" (74.46 MPS), respectively. The ninth and tenth ranks were assigned to "Mixing tonic in drinking water of brooding chick" (73.80 MPS) and "Heating brooder house before letting in the chicks" (68.22 MPS), respectively. The last eleventh rank was awarded to the least adopted practice i.e. "Removing chick guard after prescribed days" (65.63 MPS).

The data in table 4.further depict that the medium farmers were found to have highest adoption (79.00 MPS) whereas, lowest adoption (72.53 MPS) of recommended brooding practices was found among small farmers. The results might be outcome of reason that poultry farmers of the study area usually follow the brooding in the same shed in which they are to be reused further. So, very seldom the practices of using chick guards are applied. It might be concluded that the poultry farmers were found to have higher adoption of eleven brooding practices. They regulate temperature, humidity and proper ventilation during brooding and prevent over heating and chilling because the poultry farmers might have more contact with poultry department and benefited by various poultry departmental programmes introduced by the 
poultry department. These findings are in confirmation of the findings of Khati and Kumar (1996) and Rao and Mathure (2002).

Adoption of recommended litter management practices by the poultry farmers

The adoption of recommended poultry farming practices by the poultry farmers were measured for all the nine important practices of litter management. The data in the table 5 and indicate that out of nine practices of litter management, "Maintenance of required percentage of moisture in the litter" adopted by poultry farmers was occupied the highest position (92.86 MPS), hence it was ranked first. The second, third, fourth, fifth and sixth ranks were awarded to the practices "Replacement of wet and crust formed litter" (87.82 MPS), "Required thickness of litter material at the time of starting a lot" (83.89 MPS), "Use of good quality litter material" (83.41 MPS), "Spreading recommended thickness of bedding material every month" (78.63 MPS) and "Change of litter after every lot" (76.21 MPS), respectively. The seventh and eighth ranks were assigned to "Improve the quality of dropping" (73.66 MPS) and "Adopted deep litter system" (72.53 MPS), respectively. The last ninth rank was awarded to the least adopted practice "Slight hoeing of litter material at regular intervals" (70.66 MPS).

The data in table 5.3.3.3 further elucidate that the large poultry farmers were found to have highest adoption (82.01 MPS) whereas, lowest adoption of recommended litter management practices was found among small farmers (78.47 MPS). It might be concluded that the poultry farmers were found to have higher extent of adoption of nine litter management practices, they adopt only those practices which give more production such as change litter regularly and thoroughly clean and disinfect the poultry house. These findings are in agreement with the findings of Mathiyalagan (1997).

Adoption of recommended temperature and light regulation practices by the poultry farmers

The adoption of recommended poultry farming practices by the poultry farmers were measured for all the seven important practices of temperature and light regulation. The data in the table 6 and indicate that out of seven practices of temperature and light regulation, "Keeping required temperature of house during $1^{\text {st }}$ week" adopted by poultry farmers was occupied the highest position (85.78 MPS), hence it was ranked first. The second, third and fourth ranks were awarded to the practices "Give optimum light to grower" (83.22 MPS), "Use of automatic temperature regulation devices" (81.30 MPS) and "Use optimum temperature for grower" (79.54 MPS), respectively. The fifth and sixth ranks were assigned to "Fixing thermometer at recommended height on the wall" (79.51 MPS) and "Reduction of $5^{0} \mathrm{~F}$ temperature every week" (76.65 MPS), respectively. The last seventh rank was awarded to the least adopted practice "Use of alternative heating arrangement in case of power failure" (72.20 MPS). The data in table 6 further elucidate that the medium poultry farmers were found to have highest adoption (82.98 MPS) whereas, lowest adoption (77.68 MPS) of recommended temperature and light regulation practices was found among small farmers. It might be concluded that the poultry farmers were found to have higher extent of adoption of seven temperature and light regulation practices and they might have more effective adoption of temperature requirement for poultry birds during first week and about the same in the subsequent weeks.

These findings are similar with the findings of 
Nishi (1996) and Sah (1996) but contradicts with the findings of Mithyalagan (1997) and Rao and Mathure (2002).

\section{Adoption of recommended feeding} practices by the poultry farmers

The adoption of recommended poultry farming practices by the poultry farmers were measured for all the ten practices of feeding. The data in the table 7 indicate that out of ten practices of feeding, "Balanced ration for feeding poultry" adopted by poultry farmers was occupied the highest position (87.25 MPS), hence it was ranked first. The second, third, fourth, fifth, sixth and seventh ranks were awarded to the practices "Filling feeders to half level" (85.16 MPS), "Starter and finisher mesh in proper balance" (81.91 MPS), "Mixing of recommended dose of antibiotic in poultry feed" (81.24 MPS), "Using green feed for poultry" (80.82 MPS), "Recommended number of chick feeders" (80.70 MPS) and "Use of grit box in poultry house" (80.14 MPS), respectively. The eighth and ninth ranks were assigned to "Recommended ratio of poultry concentrate and grinded maize" (80.09 MPS) and "Use of poultry manure in broiler feed" (79.05 MPS), respectively. The last tenth rank was awarded to the least adopted practice "Recommended differential doses of feed to poultry birds at different age groups" (77.98 MPS).

The data in table 7 further depict that the medium farmers were found to have higher adoption (83.38 MPS) whereas, lowest adoption (79.88 MPS) of recommended feeding practices of farming was found among large farmers. It might be concluded that the poultry farmers were found to have higher extent of adoption of ten feeding practices. This might be due to the fact that poultry farmers might have learnt about good quality of commercial poultry feed or a carefully formulated home mixed feed and use only balanced feed by receiving trainings. The findings are also supported by the findings of Singh and Chahal (2000).

Adoption of recommended watering practices by the poultry farmers

The adoption of recommended poultry farming practices by the poultry farmers were measured for all the five important practices of watering. The data in table 8 indicate that out of five practices of watering, "Proper cleaning the water before serving to birds" adopted by poultry farmers was occupied the highest position (87.25 MPS), hence it was ranked first. The second, third and fourth ranks were awarded to the practices "Keeping drinkers at required distance" (81.91 MPS) "Providing water to the birds for required number of times" (81.24 MPS)" Taking proper precautions while serving water to the chicks" (77.98 MPS), respectively. The lowest rank was awared to the practice "Cleaning the chick drinkers as recommended" (73.98 MPS).

The data in table 8 further explain that the small farmers were found to have higher adoption (83.33 MPS) whereas, lowest adoption (78.53 MPS) of recommended watering practices was found among medium farmers. It might be concluded from the findings that the poultry farmers were found to have higher adoption of five watering practices and they were adopted adequate and regular supply of clean and fresh water, through waterer / nipple drinkers. The findings are in agreement with findings of Mathiyalagem (1997).

\section{Adoption of recommended equipment and spacing practices by the poultry farmers}

The adoption of recommended poultry farming practices by the poultry farmers were measured for all the eight practices of 
equipment and spacing. The data in the table 9 indicate that out of eight practices of equipment and spacing, "required waterer space to the birds at different age" adopted by poultry farmers was occupied the highest position (85.66 MPS), hence it was ranked first. The second, third, fourth and fifth ranks were awarded to the practices "required feeder space to the birds at different ages" (84.76 MPS), "required floor space to the birds at different age" (80.82 MPS), "feeders and waterers of required depth" (80.14 MPS) and "use nest box and community nest in poultry" (79.42 MPS), respectively. The sixth and seventh ranks were assigned to "use feed scoop in poultry" (79.41 MPS) and "feeders of required height" (79.05 MPS), respectively. The last eighth rank was awarded to the least adopted practice "required waterer space to the birds" (78.66 MPS).

The data in table 9 further elucidate that the medium farmers were found to have higher adoption (83.92 MPS) whereas, lowest adoption (79.46 MPS) of recommended equipment and spacing practices of poultry farming was found among large farmers. It might be concluded that poultry farmers were found to have higher adoption of eight equipment and spacing practices of poultry farming. These findings in agreement with the findings of Sihag et al., (1996) and Verma(1996) and in contradiction with the findings of Nair and Ghadolia (2000).

\section{Adoption of common disease management by the poultry farmers}

The adoption of recommended poultry farming practices by the poultry farmers were measured for all the eight important practices of disease management.

The data in the table 5.3.3.8 and Fig. 33 indicate that out of eight practices of disease management, "consult veterinarian / laboratory" adopted by poultry farmers was occupied the highest position (87.13 MPS), hence it was ranked first.

The second, third, fourth and fifth ranks were awarded to the practices "examining chicks regularly for their health" (85.88 MPS), "vaccination schedule to be followed" (83.22 MPS), "Sending dead birds for postmortem" (82.68 MPS) and "Vaccination of chicks against bird flu disease" (79.54 MPS), respectively.

The sixth and seventh ranks were assigned to "recommended doses of vaccine" (79.51 MPS) and "isolation of underdeveloped and weak chicks" (77.63 MPS), respectively. The last eighth rank was awarded to the least adopted practice "vaccination of chicks at right time" (76.35 MPS).

The data in table 10 further elucidate that the medium farmers were found to have highest adoption (85.48 MPS) whereas, lowest adoption (80.35 MPS) of recommended disease management practices of poultry farming was found among large farmers.

It might be concluded that poultry farmers were found to have higher extent of adoption of eight disease management practices.

This might be due to the fact that the poultry farmers might have more awared about paramedical facilities, high incidence of disease and their control measures. They also believed in prevention is better than cure. These findings are supported by the findings Patel et al., (1999-2000) and Sharma et al., (2000).

\section{Adoption of recommended sanitation practices by the poultry farmers}

The adoption of recommended poultry farming practices by the poultry farmers were measured for all the six important practices of sanitation. The data in the table 11 indicate 
that out of six practices of sanitation, "layer of lime or phenyl soaked footpad at the door of shed" adopted by poultry farmers was occupied the highest position (95.25 MPS), hence it was ranked first.

The second, third, fourth and fifth ranks were awarded to the practices "burying the dead birds deep into the pits" (85.87 MPS) "proper sanitary conditions inside the farm" (75.80 MPS), "proper disinfections of house before starting the lot" (73.73 MPS) and "painting floor with lime" (67.08 MPS), respectively.

The last sixth rank was awarded to the least adopted practice "restricting visits of out sides in the farm" (59.39 MPS). The data in table 11 further elucidate that the large farmers were found to have higher adoption (78.17 MPS) whereas, lowest adoption (74.65 MPS) of recommended sanitation practices of poultry farming was found among small farmers. The poultry farmers were found to have higher extent of adoption of six sanitation practices, they always avoid visitors as much as possible in poultry house.

This might be due to the fact that the poultry farmers benefited by various training programmes organized by poultry department and they might have more contacts with poultry specialists for obtaining sanitation practices. These findings are in line with the findings of Mithyalagan(1997).

\section{Adoption of recommended record keeping and marketing practices by the poultry farmers}

The adoption of recommended poultry farming practices by the poultry farmers were measured for all the seven important practices of record keeping and marketing. The data in table 12 indicate that out of seven practices of record keeping and marketing, "keeping records of poultry feed consumption" adopted by poultry farmers was occupied the highest position (85.87 MPS), hence it was ranked first. The second, third, fourth, fifth and sixth, ranks were awarded to the practices "record of bird mortality" (82.79 MPS), "keeping record of health checkup and diseases" (81.06 MPS) "keeping one-self familiar with prices of poultry products" (76.60 MPS), "selling the product at appropriate time" (74.20 MPS) and "record of day-by-day expenditure" (68.50 MPS), respectively. The last seventh rank was awarded to the least adopted practice "keeping one self aware of demand of poultry products" (76.02 MPS).

The data in table 12 further depict that the large farmers were found to have highest adoption (80.10 MPS) whereas, lowest adoption (73.74 MPS) of recommended record keeping and marketing practices of poultry farming was found among medium farmers. The inferences might be drawn from the findings that the poultry farmers were found to have higher adoption of seven record keeping and marketing practices, they were adopted suitable marketing infrastructure and streamlining the marketing and distribution network. These findings are supported by the findings of Patel et al., (1999-2000) and Sharma et al., (2000).

Practice-wise overall adoption of the poultry farmers about recommended poultry farming practices

Practice wise over all adoption of poultry farmers about recommended poultry farming practices was measured. To sum up the scores of all the major aspects of adoption the scores for the practices selected under each major aspect were summed up and have been presented in table 13. 
Table.1 Adoption of recommended poultry farming practices by the poultry farmers

\begin{tabular}{|c|c|c|c|c|c|c|c|c|c|}
\hline \multirow{3}{*}{ S.NO. } & \multirow{3}{*}{$\begin{array}{l}\text { Adoption } \\
\text { category }\end{array}$} & \multicolumn{6}{|c|}{ Category of poultry farmers } & \multirow{2}{*}{\multicolumn{2}{|c|}{ Pooled }} \\
\hline & & \multicolumn{2}{|c|}{ Large } & \multicolumn{2}{|c|}{ Medium } & \multicolumn{2}{|c|}{ Small } & & \\
\hline & & f & $\%$ & $\mathbf{f}$ & $\%$ & f & $\%$ & $\mathbf{f}$ & $\%$ \\
\hline 1. & Low $(<57.81)$ & 16 & 19.05 & 12 & 17.65 & 10 & 20.83 & 38 & 19.18 \\
\hline 2. & $\begin{array}{l}\text { Medium (from } \\
57.81 \text { to } 66.47 \text { ) }\end{array}$ & 52 & 61.90 & 53 & 77.94 & 36 & 75.00 & 141 & 71.61 \\
\hline 3. & High (> 66.47) & 16 & 19.05 & 3 & 4.41 & 2 & 4.17 & 21 & 9.21 \\
\hline & Total & 84 & 100.00 & 68 & 100.00 & 48 & 100.00 & 200 & 100.00 \\
\hline
\end{tabular}

$\overline{\mathrm{X}}=62.14, \sigma=4.33 \mathrm{f:}$ Frequency, \%: Percent

Table.2 Category-wise comparison between poultry farmers in adoption of the recommended poultry farming practices

\begin{tabular}{|c|c|c|c|c|c|}
\hline \multirow[t]{2}{*}{ S.No. } & \multirow[t]{2}{*}{ Category one } & \multirow[t]{2}{*}{ Category two } & \multicolumn{2}{|c|}{ Mean per cent score } & \multirow[t]{2}{*}{ "Z" value } \\
\hline & & & Category one & Category two & \\
\hline 1. & $\begin{array}{l}\text { Large farmers } \\
\qquad(\mathrm{N}=84)\end{array}$ & $\begin{array}{l}\text { Medium farmers } \\
(\mathrm{N}=68)\end{array}$ & 62.15 & 62.72 & $1.68 \mathrm{NS}$ \\
\hline 2. & $\begin{array}{l}\text { Large farmers } \\
\quad(\mathrm{N}=84)\end{array}$ & $\begin{array}{l}\text { Small farmers } \\
\quad(\mathrm{N}=48)\end{array}$ & 62.15 & 61.12 & $2.76 * *$ \\
\hline 3. & $\begin{array}{l}\text { Medium farmers } \\
(\mathrm{N}=68)\end{array}$ & $\begin{array}{l}\text { Small farmers } \\
(\mathrm{N}=48)\end{array}$ & 62.72 & 61.12 & $4.31 * *$ \\
\hline
\end{tabular}

** Significant at 0.01 evel of probability

NS = Non significant

Table.3 Adoption of recommended chick procurement practices by the poultry farmers

\begin{tabular}{|c|c|c|c|c|c|c|}
\hline \multirow{3}{*}{$\begin{array}{c}\text { S. } \\
\text { No }\end{array}$} & \multirow{3}{*}{ Adoption items } & \multirow{2}{*}{\multicolumn{5}{|c|}{ Category of poultry farmers }} \\
\hline & & & & & & \\
\hline & & Large & Medium & Small & Pooled & Rank \\
\hline 1. & Purchasing of chicks from reputed hatchery & 78.57 & 83.82 & 85.42 & 82.60 & I \\
\hline 2. & $\begin{array}{l}\text { Ensuring optimum weight of chicks during } \\
\text { purchase }\end{array}$ & 76.19 & 79.41 & 85.42 & 80.34 & IV \\
\hline 3. & Keeping a uniform lot of birds & 75.00 & 72.06 & 84.50 & 77.18 & VII \\
\hline 4. & Purchasing chicks of recommended breed & 84.52 & 75.00 & 83.33 & 80.95 & II \\
\hline 5. & Purchasing chicks from a nearby hatchery & 77.38 & 80.88 & 70.83 & 76.36 & VIII \\
\hline 6. & $\begin{array}{l}\text { Checking wings, legs, eyes etc. of chicks } \\
\text { while purchasing }\end{array}$ & 88.10 & 82.35 & 70.83 & 80.42 & III \\
\hline 7. & $\begin{array}{l}\text { Counting chicks before keeping them in } \\
\text { brooder }\end{array}$ & 89.29 & 74.50 & 68.75 & 77.51 & VI \\
\hline \multirow[t]{2}{*}{8.} & $\begin{array}{l}\text { Releasing chicks from the boxes at the } \\
\text { earliest }\end{array}$ & 72.35 & 76.00 & 85.42 & 77.92 & V \\
\hline & Overall & 80.17 & 78.00 & 79.31 & 79.16 & \\
\hline
\end{tabular}


Table.4 Adoption of recommended brooding practices by the poultry farmers

\begin{tabular}{|c|c|c|c|c|c|c|}
\hline \multirow{3}{*}{$\begin{array}{l}\text { S. } \\
\text { No. }\end{array}$} & \multirow[t]{3}{*}{ Adoption items } & \multicolumn{5}{|c|}{ Category of poultry farmers } \\
\hline & & \multicolumn{5}{|c|}{ Mean per cent score } \\
\hline & & Large & Medium & Small & Pooled & Rank \\
\hline 1. & $\begin{array}{c}\text { Preparing brooder house before arrival of } \\
\text { chicks }\end{array}$ & 76.19 & 83.82 & 77.08 & 79.03 & $\mathrm{~V}$ \\
\hline 2. & $\begin{array}{c}\text { Heating brooder house before letting in the } \\
\text { chicks }\end{array}$ & 83.33 & 83.82 & 37.50 & 68.22 & $\mathrm{X}$ \\
\hline 3. & $\begin{array}{l}\text { Use of thermometer for measuring } \\
\text { temperature fluctuations }\end{array}$ & 65.48 & 79.41 & 85.42 & 76.77 & VI \\
\hline 4. & $\begin{array}{l}\text { Providing proper feed and water in brooder } \\
\text { house }\end{array}$ & 83.33 & 77.94 & 85.42 & 82.23 & II \\
\hline 5. & $\begin{array}{l}\text { Spreading required thickness of bedding } \\
\text { material on brooding floor }\end{array}$ & 79.76 & 85.29 & 58.33 & 74.46 & VIII \\
\hline 6. & $\begin{array}{l}\text { Providing feed to the day old chicks on old } \\
\text { newspapers }\end{array}$ & 73.81 & 85.29 & 70.80 & 76.63 & VII \\
\hline 7. & Use of chick guard & 71.43 & 80.88 & 87.50 & 79.94 & IV \\
\hline 8. & Removing chick guard after prescribed days & 72.62 & 61.76 & 62.50 & 65.63 & XI \\
\hline 9. & $\begin{array}{c}\text { Mixing tonic in drinking water of brooding } \\
\text { chick }\end{array}$ & 76.19 & 76.47 & 68.75 & 73.80 & IX \\
\hline 10. & Use of artificial brooding & 83.33 & 72.06 & 85.42 & 80.27 & III \\
\hline \multirow[t]{2}{*}{11.} & $\begin{array}{l}\text { Dipping beaks of chicks after receiving from } \\
\text { hatchery }\end{array}$ & 88.10 & 82.35 & 79.17 & 83.21 & I \\
\hline & Overall & 77.59 & 79.00 & 72.53 & 76.38 & \\
\hline
\end{tabular}

Table.5 Adoption of recommended litter management practices by the poultry farmers

\begin{tabular}{|c|c|c|c|c|c|c|}
\hline \multirow{3}{*}{$\begin{array}{c}\text { S. } \\
\text { No. }\end{array}$} & \multirow[t]{3}{*}{ Adoption items } & \multirow{2}{*}{\multicolumn{5}{|c|}{$\begin{array}{c}\text { Category of poultry farmers } \\
\text { Mean per cent score }\end{array}$}} \\
\hline & & & & & & \\
\hline & & Large & Medium & Small & Pooled & Rank \\
\hline 1. & Use of good quality litter material & 88.10 & 80.88 & 81.25 & 83.41 & IV \\
\hline 2. & $\begin{array}{l}\text { Required thickness of litter material at } \\
\text { the time of starting a lot }\end{array}$ & 80.95 & 85.29 & 85.42 & 83.89 & III \\
\hline 3. & $\begin{array}{l}\text { Spreading recommended thickness of } \\
\text { bedding material every month }\end{array}$ & 79.76 & 85.29 & 70.83 & 78.63 & V \\
\hline 4. & $\begin{array}{l}\text { Slight hoeing of litter material at } \\
\text { regular intervals }\end{array}$ & 79.76 & 67.65 & 64.58 & 70.66 & IX \\
\hline 5. & $\begin{array}{l}\text { Maintenance of required percentage of } \\
\text { moisture in the litter }\end{array}$ & 90.48 & 98.53 & 89.58 & 92.86 & I \\
\hline 6. & $\begin{array}{l}\text { Replacement of wet and crust formed } \\
\text { litter }\end{array}$ & 88.10 & 94.12 & 81.25 & 87.82 & II \\
\hline 7. & Change of litter after every lot & 76.19 & 69.12 & 83.33 & 76.21 & VI \\
\hline 8. & Improve the quality of dropping & 82.14 & 61.76 & 77.08 & 73.66 & VII \\
\hline 9. & Adopted deep litter system & 72.62 & 72.06 & 72.92 & 72.53 & VIII \\
\hline & Overall & 82.01 & 79.41 & 78.47 & 79.96 & \\
\hline
\end{tabular}


Table.6 Adoption of recommended temperature and light regulation practices by the poultry farmers

\begin{tabular}{|c|c|c|c|c|c|c|}
\hline \multirow[t]{2}{*}{$\begin{array}{l}\text { S. } \\
\text { No }\end{array}$} & \multirow[t]{2}{*}{ Adoption items } & \multicolumn{5}{|c|}{$\begin{array}{c}\text { Category of poultry farmers } \\
\text { Mean per cent score }\end{array}$} \\
\hline & & Large & Medium & Small & Pooled & Rank \\
\hline 1. & $\begin{array}{l}\text { Keeping required temperature of } \\
\text { house during } 1^{\text {st }} \text { week }\end{array}$ & 83.33 & 82.35 & 91.67 & 85.78 & I \\
\hline 2. & $\begin{array}{c}\text { Reduction of } 5^{0} \mathrm{~F} \text { temperature every } \\
\text { week }\end{array}$ & 85.71 & 83.82 & 60.42 & 76.65 & VI \\
\hline 3. & $\begin{array}{l}\text { Use of alternative heating arrangement } \\
\text { in case of power failure }\end{array}$ & 69.05 & 80.88 & 66.67 & 72.20 & VII \\
\hline 4. & $\begin{array}{c}\text { Use of automatic temperature } \\
\text { regulation devices }\end{array}$ & 73.81 & 86.76 & 83.33 & 81.30 & III \\
\hline 5. & $\begin{array}{l}\text { Fixing thermometer at recommended } \\
\text { height on the wall }\end{array}$ & 77.38 & 88.24 & 72.92 & 79.51 & V \\
\hline 6. & Use optimum temperature for grower & 78.57 & 80.88 & 79.17 & 79.54 & IV \\
\hline \multirow[t]{2}{*}{7.} & Give optimum light to grower & 82.14 & 77.94 & 89.58 & 83.22 & II \\
\hline & Overall & 78.57 & 82.98 & 77.68 & 79.74 & \\
\hline
\end{tabular}

Table.7 Adoption of recommended feeding practices by the poultry farmers

\begin{tabular}{|c|c|c|c|c|c|c|}
\hline \multirow{3}{*}{$\begin{array}{l}\text { S. } \\
\text { No }\end{array}$} & \multirow[t]{3}{*}{ Adoption items } & \multicolumn{5}{|c|}{ Category of poultry farmers } \\
\hline & & \multicolumn{5}{|c|}{ Mean per cent score } \\
\hline & & Large & Medium & Small & Pooled & Rank \\
\hline 1. & $\begin{array}{l}\text { Recommended ratio of poultry } \\
\text { concentrate and grinded maize }\end{array}$ & 64.29 & 92.65 & 83.33 & 80.09 & VIII \\
\hline 2. & $\begin{array}{l}\text { Balanced ration for feeding } \\
\text { poultry }\end{array}$ & 88.10 & 88.24 & 85.42 & 87.25 & I \\
\hline 3. & $\begin{array}{l}\text { Mixing of recommended dose of } \\
\text { antibiotic in poultry feed }\end{array}$ & 79.76 & 76.47 & 87.50 & 81.24 & IV \\
\hline 4. & $\begin{array}{l}\text { Starter and finisher mesh in } \\
\text { proper balance }\end{array}$ & 82.14 & 82.35 & 81.25 & 81.91 & III \\
\hline 5. & $\begin{array}{l}\text { Recommended differential } \\
\text { doses of feed to poultry birds at } \\
\text { different age groups }\end{array}$ & 79.76 & 75.00 & 79.17 & 77.98 & $\mathrm{X}$ \\
\hline 6. & $\begin{array}{l}\text { Recommended number of chick } \\
\text { feeders }\end{array}$ & 80.95 & 88.24 & 72.92 & 80.70 & VI \\
\hline 7. & Filling feeders to half level & 84.52 & 89.71 & 81.25 & 85.16 & II \\
\hline 8. & Using green feed for poultry & 80.95 & 82.35 & 79.17 & 80.82 & V \\
\hline 9. & $\begin{array}{c}\text { Use of poultry manure in broiler } \\
\text { feed }\end{array}$ & 78.57 & 79.41 & 79.17 & 79.05 & IX \\
\hline 10. & Use of grit box in poultry house & 79.76 & 79.41 & 81.25 & 80.14 & VII \\
\hline & Overall & 79.88 & 83.38 & 81.04 & 81.43 & \\
\hline
\end{tabular}


Table.8 Adoption of recommended watering practices by the poultry farmers

$n=200$

\begin{tabular}{|c|c|c|c|c|c|c|}
\hline \multirow[t]{2}{*}{$\begin{array}{l}\text { S. } \\
\text { No }\end{array}$} & \multirow[t]{2}{*}{ Adoption items } & \multicolumn{5}{|c|}{$\begin{array}{c}\text { Category of poultry farmers } \\
\text { Mean per cent score }\end{array}$} \\
\hline & & Large & Medium & Small & Pooled & Rank \\
\hline 1. & $\begin{array}{l}\text { Cleaning the chick drinkers as } \\
\text { recommended }\end{array}$ & 67.86 & 70.59 & 83.33 & 73.93 & $\mathrm{~V}$ \\
\hline 2. & $\begin{array}{c}\text { Proper cleaning the water before serving to } \\
\text { birds }\end{array}$ & 88.10 & 88.24 & 85.42 & 87.25 & I \\
\hline 3. & $\begin{array}{c}\text { Providing water to the birds for required } \\
\text { number of times }\end{array}$ & 79.76 & 76.47 & 87.50 & 81.24 & III \\
\hline 4. & Keeping drinkers at required distance & 82.14 & 82.35 & 81.25 & 81.91 & II \\
\hline 5 . & $\begin{array}{l}\text { Taking proper precautions while serving } \\
\text { water to the chicks }\end{array}$ & 79.76 & 75.00 & 79.17 & 77.98 & IV \\
\hline & Overall & 79.52 & 78.53 & 83.33 & 80.46 & \\
\hline
\end{tabular}

Table.9 Adoption of recommended equipment and spacing practices by the poultry farmers

\begin{tabular}{|c|c|c|c|c|c|c|}
\hline \multirow{3}{*}{$\begin{array}{l}\text { S. } \\
\text { No }\end{array}$} & \multirow[t]{3}{*}{ Adoption items } & \multicolumn{5}{|c|}{ Category of poultry farmers } \\
\hline & & \multicolumn{5}{|c|}{ Mean per cent score } \\
\hline & & Large & Medium & Small & Pooled & Rank \\
\hline 1. & $\begin{array}{l}\text { Required feeder space to the birds } \\
\text { at different age }\end{array}$ & 83.33 & 89.71 & 81.25 & 84.76 & II \\
\hline 2. & $\begin{array}{l}\text { Required floor space to the birds at } \\
\text { different age }\end{array}$ & 80.95 & 82.35 & 79.17 & 80.82 & III \\
\hline 3. & Feeders of required height & 78.57 & 79.41 & 79.17 & 79.05 & VII \\
\hline 4. & $\begin{array}{l}\text { Feeders and waterers of required } \\
\text { depth }\end{array}$ & 79.76 & 79.41 & 81.25 & 80.14 & IV \\
\hline 5. & Required waterer space to the birds & 76.19 & 76.47 & 83.33 & 78.66 & VIII \\
\hline 6. & $\begin{array}{l}\text { Use nest box and community nest } \\
\text { in poultry }\end{array}$ & 78.57 & 86.76 & 72.92 & 79.42 & $\mathrm{~V}$ \\
\hline 7. & Use feed scoop in poultry & 75.00 & 88.24 & 75.00 & 79.41 & VI \\
\hline 8 & $\begin{array}{l}\text { Required waterer space to the birds } \\
\text { at different ages }\end{array}$ & 83.33 & 88.24 & 85.42 & 85.66 & $\mathrm{I}$ \\
\hline & Overall & 79.46 & 83.82 & 79.68 & 80.99 & \\
\hline
\end{tabular}


Table.10 Adoption of common disease management by the poultry farmers

\begin{tabular}{|c|c|c|c|c|c|c|}
\hline \multirow{3}{*}{$\begin{array}{c}\text { S. } \\
\text { No }\end{array}$} & \multirow[t]{3}{*}{ Adoption items } & \multicolumn{5}{|c|}{ Category of poultry farmers } \\
\hline & & \multicolumn{5}{|c|}{ Mean per cent score } \\
\hline & & Large & Medium & Small & Pooled & Rank \\
\hline 1. & $\begin{array}{l}\text { Examining chicks regularly for } \\
\text { their health }\end{array}$ & 82.14 & 83.82 & 91.67 & 85.88 & II \\
\hline 2. & $\begin{array}{l}\text { Isolation of underdeveloped and } \\
\text { weak chicks }\end{array}$ & 85.71 & 86.76 & 60.42 & 77.63 & VII \\
\hline 3. & $\begin{array}{l}\text { Vaccination of chicks at right } \\
\text { time }\end{array}$ & 78.57 & 83.82 & 66.67 & 76.35 & VIII \\
\hline 4. & $\begin{array}{l}\text { Sending dead birds for } \\
\text { postmortem }\end{array}$ & 75.00 & 89.71 & 83.33 & 82.68 & IV \\
\hline 5. & Recommended doses of vaccine & 77.38 & 88.24 & 72.92 & 79.51 & VI \\
\hline 6. & $\begin{array}{l}\text { Vaccination of chicks against } \\
\text { bird flue disease }\end{array}$ & 78.57 & 80.88 & 79.17 & 79.54 & $\mathrm{~V}$ \\
\hline 7. & $\begin{array}{l}\text { Vaccination schedule to be } \\
\text { followed }\end{array}$ & 82.14 & 77.94 & 89.58 & 83.22 & III \\
\hline \multirow[t]{2}{*}{8} & Consult veterinarian/laboratory & 83.33 & 92.65 & 85.42 & 87.13 & I \\
\hline & Overall & 80.35 & 85.48 & 78.64 & 81.49 & \\
\hline
\end{tabular}

Table.11 Adoption of recommended sanitation practices by the poultry farmers

\begin{tabular}{|c|c|c|c|c|c|c|}
\hline \multirow{3}{*}{$\begin{array}{l}\text { S. } \\
\text { No }\end{array}$} & \multirow{3}{*}{ Adoption items } & \multicolumn{5}{|c|}{ Category of poultry farmers } \\
\hline & & \multicolumn{5}{|c|}{ Mean per cent score } \\
\hline & & Large & Medium & Small & Pooled & Rank \\
\hline 1. & $\begin{array}{l}\text { Proper sanitary conditions inside the } \\
\text { farm. }\end{array}$ & 72.62 & 73.53 & 81.25 & 75.80 & III \\
\hline 2. & $\begin{array}{l}\text { Restricting visits of out sides in the } \\
\text { farm }\end{array}$ & 71.43 & 58.82 & 47.92 & 59.39 & VI \\
\hline 3. & $\begin{array}{l}\text { Layer of lime or phenyl soaked } \\
\text { footpad at the door of shed }\end{array}$ & 92.86 & 97.06 & 95.83 & 95.25 & I \\
\hline 4. & $\begin{array}{l}\text { Burying the dead birds deep into the } \\
\text { pits }\end{array}$ & 86.90 & 85.29 & 85.42 & 85.87 & II \\
\hline 5. & $\begin{array}{l}\text { Proper disinfections of house before } \\
\text { starting the lot }\end{array}$ & 75.00 & 69.12 & 77.08 & 73.73 & IV \\
\hline 6. & Painting floor with lime & 70.24 & 70.59 & 60.42 & 67.08 & $\mathrm{~V}$ \\
\hline & Overall & 78.17 & 75.74 & 74.65 & 76.19 & \\
\hline
\end{tabular}


Table.12 Adoption of recommended record keeping and marketing practices by the poultry farmers

\begin{tabular}{|c|c|c|c|c|c|c|}
\hline \multirow{3}{*}{$\begin{array}{l}\text { S. } \\
\text { No }\end{array}$} & \multirow[t]{3}{*}{ Adoption items } & \multicolumn{5}{|c|}{ Category of poultry farmers } \\
\hline & & \multicolumn{5}{|c|}{ Mean per cent score } \\
\hline & & Large & Medium & Small & Pooled & Rank \\
\hline 1. & $\begin{array}{l}\text { Keeping records of poultry feed } \\
\text { consumption }\end{array}$ & 86.90 & 85.29 & 85.42 & 85.87 & I \\
\hline 2. & Record of bird mortality & 79.76 & 85.29 & 83.33 & 82.79 & II \\
\hline 3. & Record of day-by-day expenditure & 71.43 & 63.24 & 70.83 & 68.50 & VI \\
\hline 4. & $\begin{array}{l}\text { Keeping one-self familiar with } \\
\text { prices of poultry products }\end{array}$ & 86.90 & 72.06 & 70.83 & 76.60 & IV \\
\hline 5. & $\begin{array}{l}\text { Keeping one self aware of demand } \\
\text { of poultry products }\end{array}$ & 72.62 & 61.76 & 66.67 & 67.02 & VII \\
\hline 6. & $\begin{array}{l}\text { Selling the product at appropriate } \\
\text { time }\end{array}$ & 77.38 & 76.47 & 68.75 & 74.20 & V \\
\hline \multirow[t]{2}{*}{7.} & $\begin{array}{l}\text { Keeping record of health checkup } \\
\text { and diseases }\end{array}$ & 85.71 & 72.06 & 85.42 & 81.06 & III \\
\hline & Overall & 80.10 & 73.74 & 75.89 & 76.58 & \\
\hline
\end{tabular}

Table.13 Practice-wise comparison of overall adoption of recommended poultry farming practices by the poultry farmers

$\mathrm{n}=200$

\begin{tabular}{|c|c|c|c|c|c|c|}
\hline \multirow{2}{*}{ S. No } & Major practices of adoption & \multicolumn{5}{|c|}{ Category of poultry farmers } \\
\cline { 3 - 7 } & & \multicolumn{4}{|c|}{ Mean per cent score } \\
\cline { 3 - 6 } & & Large & Medium & Small & Pooled & Rank \\
\hline 1 & Chick procurement practices & 71.13 & 69.48 & 70.31 & 70.25 & X \\
\hline 2 & Brooding practices & 77.60 & 79.01 & 75.19 & 77.27 & VII \\
\hline 3 & Litter management practices & 82.01 & 79.41 & 78.47 & 79.96 & V \\
\hline 4 & Temperature \& light regulation & 78.57 & 82.98 & 77.68 & 79.74 & VI \\
\hline 5 & practices & 79.88 & 83.38 & 81.04 & 81.43 & II \\
\hline 6 & Feeding practices & 79.52 & 78.53 & 83.33 & 80.46 & IV \\
\hline 7 & Watering practices & 79.46 & 83.82 & 79.69 & 80.99 & III \\
\hline 8 & Equipment and spacing practices & 80.36 & 85.48 & 78.64 & 81.49 & I \\
\hline 9 & Disease management practices & 78.17 & 75.73 & 74.65 & 76.18 & IX \\
\hline 10 & Sanitation practices & 80.18 & 73.74 & 75.89 & 76.57 & VIII \\
\hline & Record keeping and marketing & & & & & \\
\hline & practices & 78.68 & 79.16 & 77.48 & 78.43 & \\
\hline
\end{tabular}


The data in table 13 reveal that the highest adoption of poultry farmers was found about "disease management practices" (81.49 MPS), hence it was ranked first. The second and third ranks were assigned to the "feeding practices" (81.43 MPS) and "equipment and spacing practices" (80.99 MPS), respectively. The practices "watering practices", "litter management practices", "temperature \& light regulation practices", "brooding practices", "record keeping and marketing practices", and "sanitation practices" were obtained the 80.46 , 79.96, 79.94, 77.27, 76.57 and 76.18 MPS and ranks were assigned fourth, fifth, sixth, seventh, eighth and ninth, respectively. The lowest rank was awarded to the practice "chick procurement practices" (70.25 MPS).

Regarding different categories of poultry farmers, the large, and medium poultry farmers were having maximum adoption about the practice "litter management practices" and "disease management practices" and obtained MPS 82.01, and 85.48, respectively whereas, small poultry farmers were having maximum adoption scores about "watering practices" (83.33 MPS). The lowest adoption scores of large, medium and small poultry farmers were found about the "chick procurement practices" and obtained MPS 71.13, 69.48 and 70.31, respectively. The data in table 5.3.3.11 also indicate that almost all the medium poultry farmers were having higher adoption (79.16 MPS) about all equipment and spacing practices. All small farmers were having lower adoption (77.48 MPS) about all the tenth practices. These findings are in line with the findings of Kavad et al., (1997-98), Patel and Acharya(1997-98).

\section{References}

Kavad, S. D., Patel, R. B. and Joshi, V. D. (1997-98). "Impact of cooperative sugar factories on sugarcane growers of south
Gujarat". Guj. Journ. of Extn. Edn.:Vol VIII \& IX : 125-127.

Mundhawa, A. B., Patel, A. A. and Patel, B. T. (1997-98). 'Grower's adoption behavior of production technologies of irrigated wheat". Guj. Journ. of ExtnEdn. Vol.: VIII \& IX: 1-5.

Mathiyalagan, P. (1997). "Acceptance pattern of poultry farm practices". Maha. Journ. of Extn. Edn. XVI : 100-103.

Mathur, P. (2001). "Problems and prospects of improved cattle management in Arid Western Plain Zone of Rajasthan". Ph.D. Thesis, MPUAT, Udaipur (Rajasthan).

Nishi, (1996). "Comparative study of beneficiaries and non-beneficiaries of Intensive Mini Dairy Project, Lucknow (U.P.)". M.Sc. Thesis, NDRI, Karnal.

Nair, B.C. and Ghadoliya, P. (2000). "Economic viability of layer farming in the state of Goa". Ind. J. of Poultry Sci., XXXV (1): 73-76.

Patel, A. A. and Patel, R. K. (1999-2000). "Growers managerial ability for plant protection measures in Chilli crop". Guj. Journ. ofExtn. Edn. Vol. X \& XI: 1-4.

Patel, B. S. and Acharya, R. R. (1997-98). "Impact of tribal training center on knowledge and adoption of participant and non-participant farmers in Dahod district". Guj. Journ. of Extn. Edn. Vol.: X \& XI: 65-66.

Sihag, S.; Grover, I. and Sihag, S. Z. (1996). "Adoption of animal husbandry innovations by the rural women". Indian Journal of Animal Production Management, 2 (1) : 24-29.

Singh, B. and Chahal, S. M. (2000). "Adoption of approved practices and constraint analysis for broiler production in Jind district of Harayana state". Proceeding of International Conference on Small Holder Livestock Production System in Developing Countries, Nov. 24-27, Thrissur, Kerala, India. 


\section{How to cite this article:}

Hanuman Sahay Bunkar and Bangarwa, G. S. 2021. Extent of Adoption of Recommended Poultry Farming Practices by the Farmers. Int.J.Curr.Microbiol.App.Sci. 10(09): 38-53. doi: https://doi.org/10.20546/ijcmas.2021.1009.005 